\title{
OPEN
}

Published online: 06 February 2020

\section{Author Correction: Precision and safety of Multilevel Cervical Transpedicular Screw Fixation with 3D Patient-Specific Guides; A Cadaveric Study}

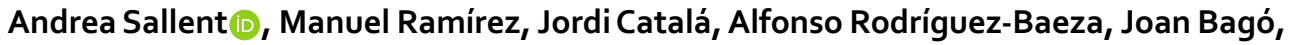 Matías de Albert \& Roberto Vélez}

Correction to: Scientific Reports https://doi.org/10.1038/s41598-019-51936-w, published online 30 October 2019

The Acknowledgements section in this Article is incomplete.

"Authors would like to special thank Instituto Guirado (Barcelona, Spain), for performing all CT scans for the present study. Authors would like to thank Avinent Implant System, S.L., Santpedor, Spain for printing the 3D guides."

should read:

"Authors would like to special thank Instituto Guirado (Barcelona, Spain), for performing all CT scans for the present study. Authors would like to thank Avinent Implant System, S.L., Santpedor, Spain for printing the 3D guides. Authors would like to appreciate MBA Institut for their help with the surgical material and during the surgical procedure."

(i) Open Access This article is licensed under a Creative Commons Attribution 4.0 International License, which permits use, sharing, adaptation, distribution and reproduction in any medium or format, as long as you give appropriate credit to the original author(s) and the source, provide a link to the Creative Commons license, and indicate if changes were made. The images or other third party material in this article are included in the article's Creative Commons license, unless indicated otherwise in a credit line to the material. If material is not included in the article's Creative Commons license and your intended use is not permitted by statutory regulation or exceeds the permitted use, you will need to obtain permission directly from the copyright holder. To view a copy of this license, visit http://creativecommons.org/licenses/by/4.0/.

(c) The Author(s) 2020 